\title{
The Effect of Work Discipline and Motivation on Employee Performance (at PT. Bank Mandiri Ciledug Branch)
}

\author{
Priehadi Dhasa Eka \\ Universitas Pamulang \\ E-mail: dosen01577@ unpam.ac.id
}

(Received: May-2018; Reviewed: June-2018; Accepted: August-2018;

Avalaibel Online: August -2018; Published: September-2018)

(7) \& This is an open access article distributed under the Creative Commons Attribution License CC-BY-NC-4.0 (2018 by author (https://creativecommons.org/licenses/by-nc/4.0/)

\begin{abstract}
Human resources are one of the factors directly involved in carrying out company activities. This study aims to determine the effect of work discipline and motivation on employee performance at PT. Bank Mandiri Ciledug Branch. The method used in this research is descriptive method with an associative approach with proportional random sampling technique. Methods of data analysis using descriptive and verification with regression analysis, determination, and hypothesis testing partially or simultaneously. The results showed that partially the independent variables affect the dependent variable. Simultaneously testing the influence also concluded work discipline, and motivation had a positive and significant effect on employee performance with an influence contribution of $41.1 \%$. Hypothesis testing obtained a probability statistic value $<0.05$ thus $\mathrm{H} 0$ is rejected and $\mathrm{H} 1$ is accepted.
\end{abstract}

Keywords: Work discipline; motivation; employee performance

\section{INTRODUCTION}

The role of employees is very important in an organization because the human element is one of the elements that can play an active role in the policy and achievement of organizational goals. With reliable human resources, the company's operational activities will run smoothly. Human resources are one of the factors directly involved in carrying out company activities and at war is important in increasing company productivity in achieving the goals set (Dessler, 2015; Rahadi, 2010; E. Sari, 2008)

PT. Bank Mandiri is determined to become the leading financial institution in Indonesia that serves all segments, by offering value based on excellence supported by technology (Firmandari, 2014; Kusumo, 2008; R. Sari, Muis, \& Hamid, 2012). In order to align the vision and mission, PT. Bank Mandiri continues to strive to provide the best service by consistently focusing on service to the community. Associated with the implementation of the ASEAN 
Economic Community (AEC) is the readiness of human resources, the company conducts banking activities with priority on excellent service.

Good work discipline reflects the magnitude of one's sense of responsibility towards a given task. This can encourage workplace enthusiasm, work morale, efficiency, and work effectiveness (Saleh, 2014; Sarman, Akib, \& Niswaty, 2015; Sunarsi, 2014, 2017, 2018; Wairooy, 2017). Discipline is one's awareness and willingness to obey the rules of all companies and the prevailing social norms (Mangkunegara \& Octorend, 2015; Saleh, 2014; Wairooy, 2017; Waris, 2015). The meaning of awareness is the attitude of someone who voluntarily obeys all the rules and is aware of their duties and responsibilities. High discipline will stimulate and encourage morale to perform well in accordance with the goals of the organization.

The importance of work motivation for a company that is as a factor driving employees. Every activity carried out by someone must have a factor that drives these activities (Astuti \& Sudharma, 2013; Fadhil \& Mayowan, 2018; Juniantara \& Riana, 2015; Rosmani, Amirullah, \& Saleh, 2015). Therefore the driving factor is the needs and desires of the employee. Performance can be assessed from the work motivation of employees. One of the motivations given by the company is the provision of appropriate compensation from the performance generated in completing the employee's duties (Gunawan, Yunus, \& Amri, 2013; Juliningrum \& Sudiro, 2011; Pane \& Astuti, 2009; Pioh \& Tawas, 2016).

Providing motivation means giving employees the opportunity to work well and get what is expected so that employees are able to develop their abilities. The role of motivation is to intensify these desires and desires, therefore it can be concluded that efforts to increase one's morale will always be associated with motivating efforts so that to carry out good motivation needs to know human needs.

Decreased morale can occur due to a lack of discipline and decreased employee motivation. Motivation describes an employee's personal desire to work in earnest. Performance improvement cannot be done without good management. The management must be a planning, implementation, monitoring and evaluation cycle. The results of the performance evaluation become feedback for the next planning stage. Every organization expects that its employees can perform well. Information about employee performance is obtained through performance appraisal. From the results of employee performance evaluations, it can be seen whether an employee can work well or not as seen from the assessment categories that are compared between benchmarks for evaluating organizational performance with employee performance. So it can be interpreted that the higher assessment is an indication that the employee's performance is able to meet organizational performance expectations (Ainnisya \& Susilowati, 2018; Amalia \& Utami, 2018; Marginingsih, 2017).

\section{METHOD}

The type of data used is quantitative with primary data sources by distributing questionnaires which are then carried out tabulation and feasibility analysis as well as secondary data from the various scientific literature. The population in this study were employees of PT. Bank Mandiri Ciledug Branch. Sampling was used a saturated sampling technique that is 60 employees. The instrument testing uses validity and reliability tests. From the validity and reliability test stated valid and reliable, this is evidenced by the value of $r$ count $>r$ table, as well as the instrument used is appropriate and feasible to be forwarded to the next test. Testing for normality using the P-P plot diagram, obtained normal chart patterns with the distribution following a diagonal line. Heteroskedasticity test with scatter plot test obtained the pattern of the distribution of residue points that do not form certain patterns. Multicollinearity testing concluded there was no multicollinearity as evidenced by the obtained value of Variance 
Inflation Factor (VIF), each independent variable had a tolerance value $<1$ and a VIF value $<10$. The autocorrelation test obtained a Durbin-Watson value of 1,659 which means it was between $(1,550-2,460)$, thus this regression model does not have autocorrelation.

\section{RESULT AND DISCUSSION}

Achievement of employee work such as a large number of employees with low attendance, completion of work that is not in accordance with the desired target, the service is less fast, and low discipline can reduce performance achievement. This condition needs to get the attention of the leadership so that employee performance will be better in the future by applying total discipline from the lower levels to the leadership. From the analysis of the coefficient of determination obtained the influence of the independent variables on the dependent variable as follows:

\section{Effect of Work Discipline (X1) on Employee Performance (Y)}

Table 1

Simple Disciplinary Linear Regression Results (X1)

\begin{tabular}{|c|c|c|c|c|c|c|}
\hline & 1 & Coel & icients ${ }^{\mathrm{a}}$ & & & \\
\hline & & $\begin{array}{l}\text { Unstan } \\
\text { Coeff }\end{array}$ & $\begin{array}{l}\text { ardized } \\
\text { ients }\end{array}$ & $\begin{array}{l}\text { Standardized } \\
\text { Coefficients }\end{array}$ & & \\
\hline Model & & B & Std. Error & Beta & $t$ & Sig. \\
\hline 1 & (Constant) & 20.129 & 4.902 & & 4.107 & .000 \\
\hline & Work Discipline (X1) & .578 & .105 & .587 & 5.527 & .000 \\
\hline
\end{tabular}

a. Dependent Variable: Work Performance $(\mathrm{Y})$

Obtained a regression equation $\mathrm{Y}=20.129+0.578$.

A constant value of 20.129, if the variables X1 and X2 do not exist or are constant or zero, then there has been an employee's performance of 20.129 points. A b value of 0.578 indicates what if the constant is constant and there is no change in the $\mathrm{X} 2$ variable then every change of 1 unit in the $\mathrm{X} 1$ variable will result in a change in $\mathrm{Y}$ of 0.578 points. This effect is positive because the regression coefficient number is positive.

Table 2

Results of the Work Discipline Determination Coefficient (X1)

Model Summary

\begin{tabular}{lrr|rr|rr} 
Model & & & & \multicolumn{2}{c}{$\begin{array}{c}\text { Std. Error of the } \\
\text { Estimate }\end{array}$} \\
\hline 1 & $\mathrm{R}$ & & R Square & Adjusted R Square & \multicolumn{2}{c}{3.337} \\
\hline
\end{tabular}

a. Predictors: (Constant), Work Discipline (X1)

Obtained R-squared of 0.345 thus contributing to the influence of work discipline on employee performance by $34.5 \%$. Hypothesis testing is partially using the T-test and simultaneously using the F-test. 
Table 3

Hypothesis test results of work discipline variables (X1)

\begin{tabular}{|c|c|c|c|c|c|c|}
\hline \multicolumn{7}{|c|}{ Coefficients $^{a}$} \\
\hline \multirow{2}{*}{\multicolumn{2}{|c|}{ Model }} & \multicolumn{2}{|c|}{$\begin{array}{l}\text { Unstandardized } \\
\text { Coefficients }\end{array}$} & \multirow{2}{*}{$\begin{array}{c}\text { Standardized } \\
\text { Coefficients } \\
\text { Beta }\end{array}$} & \multirow[b]{2}{*}{$\mathrm{t}$} & \multirow[b]{2}{*}{ Sig. } \\
\hline & & $\mathrm{B}$ & Std. Error & & & \\
\hline 1 & (Constant) & 20.129 & 4.902 & & 4.107 & .000 \\
\hline & Work Discipline (X1) & .578 & .105 & .587 & 5.527 & .000 \\
\hline
\end{tabular}

a. Dependent Variable: Work Performance $(Y)$

Obtained $t$ value $>t$ table $(5,527>2,002)$, it also strengthened with a significance of 0,000 $<0.05$. Related to the results obtained. Positive and significant results are needed between work discipline on employee performance.

\section{Effect of Motivation (X2) on Employee Performance (Y)}

Tabel 4.

Motivational Simple Linear Regression Results (X2)

\begin{tabular}{|c|c|c|c|c|c|c|}
\hline \multicolumn{7}{|c|}{ Coefficients $^{a}$} \\
\hline \multirow{2}{*}{\multicolumn{2}{|c|}{ 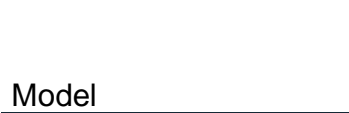 }} & \multicolumn{2}{|c|}{ Unstandardized Coefficients } & \multirow{2}{*}{$\begin{array}{c}\text { Standardized } \\
\text { Coefficients } \\
\text { Beta }\end{array}$} & \multirow[b]{2}{*}{$t$} & \multirow[b]{2}{*}{ Sig. } \\
\hline & & B & Std. Error & & & \\
\hline \multirow[t]{2}{*}{1} & (Constant) & 22.161 & 4.506 & & 4.919 & .000 \\
\hline & Motivation (X2) & .542 & .097 & .590 & 5.564 & .000 \\
\hline
\end{tabular}

a. Dependent Variable: Work Performance $(\mathrm{Y})$

Obtained regression equation $\mathrm{Y}=22.161+0.542$.

The constant value is 22,161 , if the variables $\mathrm{X} 1$ and $\mathrm{X} 2$ are missing or constant or zero then there is an employee's performance of 22,161 points. A b value of 0.542 indicates what if the constant is constant and there is no change in the $\mathrm{X} 1$ variable, each change of 1 unit in the $\mathrm{X} 2$ variable will result in a change in $\mathrm{Y}$ of 0.542 points. This effect is positive because the regression coefficient number is positive.

Table 5.

Motivation Determination Coefficient Results (X2)

Model Summary

\begin{tabular}{|c|c|c|c|c|}
\hline Model & $\mathrm{R}$ & R Square & Adjusted R Square & $\begin{array}{l}\text { Std. Error of the } \\
\text { Estimate }\end{array}$ \\
\hline 1 & $.590^{\mathrm{a}}$ & .348 & .337 & 3.329 \\
\hline
\end{tabular}

Obtained R-squared of 0.348 thus contributing to the influence of motivation (X2) on employee performance (Y) of $34.8 \%$.

Table 6

Motivation variable hypothesis test results (X2)

\begin{tabular}{|c|c|c|c|c|c|c|}
\hline \multirow[b]{3}{*}{ Model } & \multicolumn{6}{|c|}{ Coefficients $^{a}$} \\
\hline & & \multicolumn{2}{|c|}{$\begin{array}{l}\text { Unstandardized } \\
\text { Coefficients }\end{array}$} & \multirow{2}{*}{$\begin{array}{l}\text { Standardized } \\
\text { Coefficients } \\
\text { Beta }\end{array}$} & \multirow[b]{2}{*}{ t } & \multirow[b]{2}{*}{ Sig. } \\
\hline & & B & Std. Error & & & \\
\hline \multirow[t]{2}{*}{$\overline{1}$} & (Constant) & 22.161 & 4.506 & & 4.919 & .000 \\
\hline & Motivation (X2) & .542 & .097 & .590 & 5.564 & .000 \\
\hline
\end{tabular}


a. Dependent Variable: Employee Performance $(\mathrm{Y})$

Obtained $t_{\text {count }}>t_{\text {table }}(5.564>2.002)$, it was also strengthened by the significance of 0,000 $<0.05$. Therefore, there is a positive and significant influence between work motivation on employee performance.

\section{Effect of Work Discipline (X1) and Motivation (X2) on Employee Performance (Y)}

Simultaneous influence analysis is intended to determine the relationship or effect of the independent variables on the dependent variable. In this analysis multiple regression analysis is used which results are as follows:

Table 7.

Multiple Regression Results

\section{Coefficients $^{\mathrm{a}}$}

\begin{tabular}{|c|c|c|c|c|c|c|}
\hline \multirow{2}{*}{\multicolumn{2}{|c|}{ Model }} & \multicolumn{2}{|c|}{ Unstandardized Coefficients } & \multirow{2}{*}{$\begin{array}{c}\text { Standardized } \\
\text { Coefficients } \\
\text { Beta }\end{array}$} & \multirow[b]{2}{*}{$\mathrm{t}$} & \multirow[b]{2}{*}{ Sig. } \\
\hline & & B & Std. Error & & & \\
\hline 1 & (Constant) & 16.301 & 4.925 & & 3.310 & .002 \\
\hline & Work Discipline (X1) & .340 & .137 & .345 & 2.475 & .016 \\
\hline & Motivation (X2) & .325 & .128 & .353 & 2.534 & .014 \\
\hline
\end{tabular}

a. Dependent Variable: Employee Performance (Y)

Obtained a regression equation $\mathrm{Y}=16.301+03406 \mathrm{X} 1+0.325 \mathrm{X} 2$.

Each variable is positive. Thus every change in the increase in the independent variable will have positive implications in the form of an increase in the dependent variable.

Table 8.

Simultaneous Determination Coefficient Results

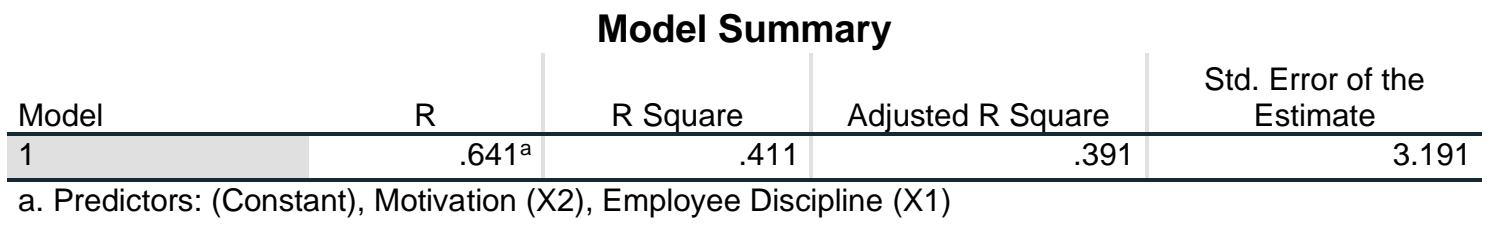

Obtained R-squared of 0.411 thus contributing simultaneously to the influence of work discipline (X1) and motivation (X2) on employee performance (Y) of $41.1 \%$.

Table 9

Simultaneous hypothesis test results

\begin{tabular}{|c|c|c|c|c|c|c|}
\hline \multicolumn{7}{|c|}{ ANOVA $^{a}$} \\
\hline \multicolumn{2}{|c|}{ Model } & $\begin{array}{l}\text { Sum of } \\
\text { Squares }\end{array}$ & df & Mean Square & $F$ & Sig. \\
\hline \multirow[t]{3}{*}{1} & Regression & 405.635 & 2 & 202.817 & 19.913 & $.000^{b}$ \\
\hline & Residual & 580.548 & 57 & 10.185 & & \\
\hline & Total & 986.183 & 59 & & & \\
\hline
\end{tabular}

a. Dependent Variable: Employee Performance (Y)

b. Predictors: (Constant), Motivation(X2), Work Discipline (X1)

Based on the above table, the obtained $F_{\text {count }}$ is greater than $F_{\text {table }}$ or $(19,913>2.770)$, thus $\mathrm{H} 0$ is rejected and $\mathrm{H} 1$ is accepted. This means that together there is a positive and significant influence between work discipline and motivation on employee performance. 


\section{CONCLUSION}

Based on the results of the study found that work discipline partially has a positive and significant effect on employee performance with a contribution of $34.5 \%$. Motivation is a partially positive and significant effect on employee performance with a contribution of $34.8 \%$. Work discipline and motivation simultaneously have a positive and significant effect on employee performance with an influence contribution of $41.1 \%$. Hypothesis testing the significance probability value $<0.05$, so that $\mathrm{H} 3$ is accepted.

\section{REFERENCES}

Ainnisya, R. N., \& Susilowati, I. H. (2018). Pengaruh Penilaian Kinerja Terhadap Motivasi Kerja Karyawan Pada Hotel Cipta Mampang Jakarta Selatan. Widya Cipta - Jurnal Sekretari dan Manajemen.

Amalia, R. M., \& Utami, D. Y. (2018). Pemberian Reward Berdasarkan Penilaian Kinerja Karyawan Dengan Metode Ahp Pada Pt. Anugerah Protecindo. JITK (Jurnal Ilmu Pengetahuan Dan Teknologi Komputer).

Astuti, N., \& Sudharma, I. (2013). Pengaruh Kompensasi Dan Motivasi Terhadap Kepuasan Dan Kinerja Karyawan Pada Hotel Bakung's Beach Cottages Kuta-Bali. E-Jurnal Manajemen Universitas Udayana.

Dessler, G. (2015). Manajemen Sumber Daya Manusia. In Jakarta: Salemba Empat.

Fadhil, A., \& Mayowan, Y. (2018). Pengaruh Motivasi Kerja Dan Kepuasan Kerja Terhadap Kinerja Karyawan Ajb Bumiputera. Jurnal Administrasi Bisnis.

Firmandari, N. (2014). Pengaruh Kompensasi Terhadap Kinerja Karyawan Dengan Motivasi Kerja Sebagai Variabel Moderasi (Studi Pada Bank Syariah Mandiri Kantor Cabang Yogyakarta). Ekbisi.

Gunawan, D., Yunus, M., \& Amri. (2013). Pengaruh Lingkungan Organisasi, Kompensasi Dan Disiplin Kerja Terhadap Motivasi Kerja Serta Dampaknya Terhadap Kinerja Pegawai Kantor Pertanahan Kota Banda Aceh. Jurnal Manajemen.

Juliningrum, E., \& Sudiro, A. (2011). Pengaruh Kompensasi, Budaya Organisasi, terhadap Motivasi Kerja dan Kinerja Pegawai. Jurnaljam.Ub.Ac.Id.

Juniantara, I. W., \& Riana, I. G. (2015). Pengaruh Motivasi dan Kepuasan Kerja terhadap Kinerja Karyawan Koperasi di Denpasar. E-Jurnal Ekonomi dan Bisnis.

Kusumo, Y. A. (2008). Analisis Kinerja Keuangan Bank Syariah Mandiri Periode 2002 - 2007 (dengan Pendekatan PBI No. 9/1/PBI/2007). La_Riba. https://doi.org/10.20885/lariba.vol2.iss1.art8

Mangkunegara, A. P., \& Octorend, T. R. (2015). Effect of Work Discipline, Work Motivation and Job Satisfaction on Employee Organizational Commitment in the Company (Case Study in PT. Dada Indonesia). Universal Journal of Management. https://doi.org/10.13189/ujm.2015.030803

Marginingsih, R. (2017). Penilaian Kinerja Perusahaan Dengan Menggunakan Analisa Rasio Keuangan Pada Perusahaan Telekomunikasi Di Indonesia. Cakrawala - Jurnal Humaniora. 
Pane, J., \& Astuti, S. D. (2009). Pengaruh Budaya Organisasi, Kepemimpinan, Transformasional, Dan Kompensasi Terhadap Kinerja Karyawan (Studi Kasus Pada Kantor Telkom Divre IV di Semarang). Jurnal Telaah Manajemen.

Pioh, N. L., \& Tawas, H. N. (2016). Pengaruh Kompensasi dan Lingkungan Kerja terhadap Kepuasan Kerja dan Kinerja Pegawai ( Studi Pada Pns Di Kantor Kecamatan Sonder Kabupaten Minahasa ). Jurnal EMBA.

Rahadi, D. R. (2010). Manajemen Kinerja Sumber Daya Manusia. In Applied Physics A: Materials Science and Processing. https://doi.org/10.1007/s00339-002-1913-7

Rosmani, S. R., Amirullah, A. H., \& Saleh, S. (2015). PENGARUH MOTIVASI KERJA TERHADAP KINERJA PEGAWAI PADA DINAS KEBERSIHAN DAN PERTAMANAN KABUPATEN SOPPENG. Jurnal Office, 1(1), 31-37.

Saleh, S. (2014). Penegakan Disiplin (Suatu Upaya Peningkatan Kinerja Pegawai). Jurnal Ad'ministrare, 1(1), 8-19.

Sari, E. (2008). Manajemen Sumber Daya Manusia Teori dan Aplikasi. In Journal of Chemical Information and Modeling.

Sari, R., Muis, M., \& Hamid, N. (2012). Pengaruh Kepemimpinan, Motivasi, Dan Stres Kerja Terhadap Kinerja Karyawan Pada Bank Syariah Mandiri Kantor Cabang Makassar. Jurnal Analisis.

Sarman, H., Akib, H., \& Niswaty, R. (2015). Pengaruh Pengawasan Terhadap Disiplin Kerja Pegawai Pada Kantor Kecamatan Ujung Kota Parepare. Jurnal Office, 1(2), 115-122.

Sunarsi, D. (2014). Pengaruh Gaya Kepemimpinan, Disiplin dan Motivasi Terhadap Kinerja. Tesis. Fakultas Ekonomi Universitas Pamulang.

Sunarsi, D. (2017). Pengaruh Disiplin, Motivasi, Dan Kompetensi Terhadap Prestasi Belajar (Studi Kasus Pada Mahasiswa Universitas Pamulang, Tangerang Selatan Tahun Akademik 2016-2017). Jurnal Mandiri: Ilmu Pengetahuan, Seni, dan Teknologi, 1(2), 207-226.

Sunarsi, D. (2018). Pengaruh Gaya Kepemimpinan, Motivasi Dan Disiplin Kerja Terhadap Kinerja Pendidik Yayasan Marvin. Inovasi, 5(1), 1-18.

Wairooy, A. (2017). Pengaruh Disiplin Kerja dan Kompensasi Terhadap Kinerja Karyawan pada PT. Pertamina (Persero), Tbk. Pemasaran Region VII Makassar. Jurnal Ad'ministrare: Jurnal Pemikiran Ilmiah dan Pendidikan Administrasi Perkantoran, 4(1), $15-24$.

Waris, A. P. M. dan A. (2015). Effect of Training, Competence and Discipline on Employee Performance in Company (Case Study in PT. Asuransi Bangun Askrida). Procedia Social and Behavioral Sciences. https://doi.org/10.1016/j.sbspro.2015.11.165 
Pinisi Discretion Review

Volume 2, Issue 1, September, 2018 Page. 61- 68 